\title{
Mid-ocean exchange of container vessel ballast water. 2: Effects of vessel type in the transport of diatoms and dinoflagellates from Manzanillo, Mexico, to Hong Kong, China
}

\author{
Mike Dickman*, Fangzhu Zhang \\ Department of Ecology \& Biodiversity, University of Hong Kong, Hong Kong, China
}

\begin{abstract}
Plankton samples were collected from 4 container ships which took on ballast water in Manzanillo, Mexico, and discharged it 21 d later in Hong Kong, China. As expected, the lack of light during transport in ballast tanks was inimical to the survival of many autotrophic (phytoplankton) species. After $21 \mathrm{~d}$ at sea, few of the dinoflagellate and diatom species taken on in Manzanillo Harbour were alive in the ballast water delivered to Hong Kong. In addition, 5 ships from Manzanillo which reballasted with open ocean water were sampled. To assess the effectiveness of mid-ocean exchange, the mean number of diatoms and dinoflagellates in the coastal ballast water ( 838 cells $\mathrm{l}^{-1}$ ) was compared with the number in the open ocean ballast water ( $436 \mathrm{cells}^{-1}$ ) delivered to Hong Kong. Open ocean exchange of ballast water (reballasting) was $48 \%$ effective in reducing diatom and dinoflagellate abundance. When we compared the Manzanillo study with our previous study of ships from Oakland, California, we concluded that the older container ships such as those coming from Manzanillo were not as effective in getting rid of diatom and dinoflagellate species as the newer container ships. This is probably because the reballasting design of the older ships is not as efficient in removing the water and sediments located near the bottom of the ballast tanks. This bottom water is associated with a large number of resting cysts and cells.
\end{abstract}

KEY WORDS: Ballast water - Efficiency of open ocean exchange - Non-indigenous species - Harmful species - Diatoms - Dinoflagellates - Manzanillo, Mexico · Hong Kong, China

\section{INTRODUCTION}

The impact of non-indigenous (exotic) species on marine coastal waters has recently received a great deal of attention (Hutchings 1992, Carlton 1996, Cohen \& Carlton 1996, Chu et al. 1997, Ruiz et al. 1997). As the size and speed of modern-day container ships have increased, so too has the invasion rate of nonindigenous marine species (Hallegraeff 1993).

According to Ruiz et al. (1997), the global movement of ballast water by ships is the largest single factor associated with the transfer of non-indigenous marine species in coastal waters. It is estimated that about

\footnotetext{
•E-mail: dickman@hkusua.hku.hk
}

10 billion tonnes of ballast water is transported around the world each year (Rigby et al. 1995). Ballast water has been regarded as an international pollutant of major consequence. Open ocean exchange was recommended by the International Maritime Organisation as a means of controlling the spread of non-indigenous species (Jones 1991, Carlton \& Geller 1993, Hallegraeff 1993).

The open ocean exchange of ballast water is relatively inexpensive and more environmentally friendly than killing exotic species by treating ballast water with chlorine or other powerful oxidizing agents (Rigby \& Hallegraeff 1996). Unlike coastal and estuarine waters that are rich in nutrients and planktonic life forms, open ocean waters contain relatively few organisms and low nutrient levels (Rigby et al. 1995). Fur- 
Table 1. Voyage start and end dates, duration, sample date and ballast water exchange dates and locations for the 5 occasions vessels carried out open ocean exchange

\begin{tabular}{|lcccccc}
\hline Sample date & Vessel name & Voyage dates & $\begin{array}{c}\text { Ballast water } \\
\text { exchange date }\end{array}$ & $\begin{array}{c}\text { Location } \\
\text { Latitude } \\
\text { Longitude }\end{array}$ duration (d) \\
\hline 24 Nov 1996 & 'TMM Veracruz' & 3 Nov 1996-24 Nov 1996 & 18 Nov 1996 & $33.00^{\circ} \mathrm{N}$ & $155.58^{\circ} \mathrm{E}$ & 21 \\
16 Feb 1997 & 'TMM Veracruz' & 26 Jan 1997-16 Feb 1997 & 10 Feb 1997 & $43.06^{\circ} \mathrm{N}$ & $149.20^{\circ} \mathrm{E}$ & 21 \\
30 Mar 1997 & 'TMM Veracruz' & 9 Mar 1997-30 Mar 1997 & 22 Mar 1997 & $53.19^{\circ} \mathrm{N}$ & $177.05^{\circ} \mathrm{E}$ & 21 \\
12 Jan 1998 & 'Eagle Malaysia' & 22 Dec 1997-12 Jan 1998 & 29 Dec 1997 & $32.59^{\circ} \mathrm{N}$ & $165.20^{\circ} \mathrm{E}$ & 21 \\
19 Jan 1998 & 'TMM Veracruz' & 29 Dec 1997-19 Jan 1998 & 12 Jan 1998 & $44.06^{\circ} \mathrm{N}$ & $150.56^{\circ} \mathrm{E}$ & 21 \\
\hline
\end{tabular}

thermore, open ocean organisms are considered unlikely to adapt readily to coastal environments, and hence the probability of transfer and survival of unwanted organisms is greatly reduced. Initial thoughts were that mid-ocean exchange would prove to be an effective control measure. However, the effectiveness of ballast water exchange as a preventive strategy is not yet fully supported by scientific evidence (Rigby et al. 1993).

To test the effectiveness of open ocean exchange, the ballast water from 3 large container ships, the 'Eagle Anahuac', the 'Eagle Malaysia' and the 'TMM Veracruz', was sampled during the period June 1996 to January 1998. The ships sailed from Manzanillo, Mexico, to Hong Kong, China, stopping en route at Yokohama, Japan, followed by Kobe, Japan, and Kaohsiung, Taiwan. They returned via the same route (Fig. 1), taking 42 d to make the round trip. Ships leaving Manzanillo would either sail directly to Yokohama or would reballast by stopping in $>2000 \mathrm{~m}$ of water to discharge Manzanillo coastal ballast water and take on 'open ocean' water. The latitude and longitude of the reballasting location are given in Table 1 . On 5 occasions we sampled ships which had exchanged their ballast water for open ocean water, and on 4 occasions ships which retained the ballast water taken on in Manzanillo until they reached Hong Kong.

Upon arrival in Hong Kong, the ballast water was removed from ballast tank no. 1 (bow) and examined using a scanning electron microscope (SEM) and light microscope to assess the number of diatom and dinoflagellate species in the ballast water.

Concurrent with this study of reballasting efficiency for Manzanillo container ships was a second study of harmful diatoms and dinoflagellates in California container ship ballast water. This second study was carried out from April 1996 to April 1997 (Zhang \& Dickman 1998 , this volume). Ballast water samples were collected from 34 OOCL ships which took approximately $16 \mathrm{~d}$ to travel from Oakland, California (USA), to Hong

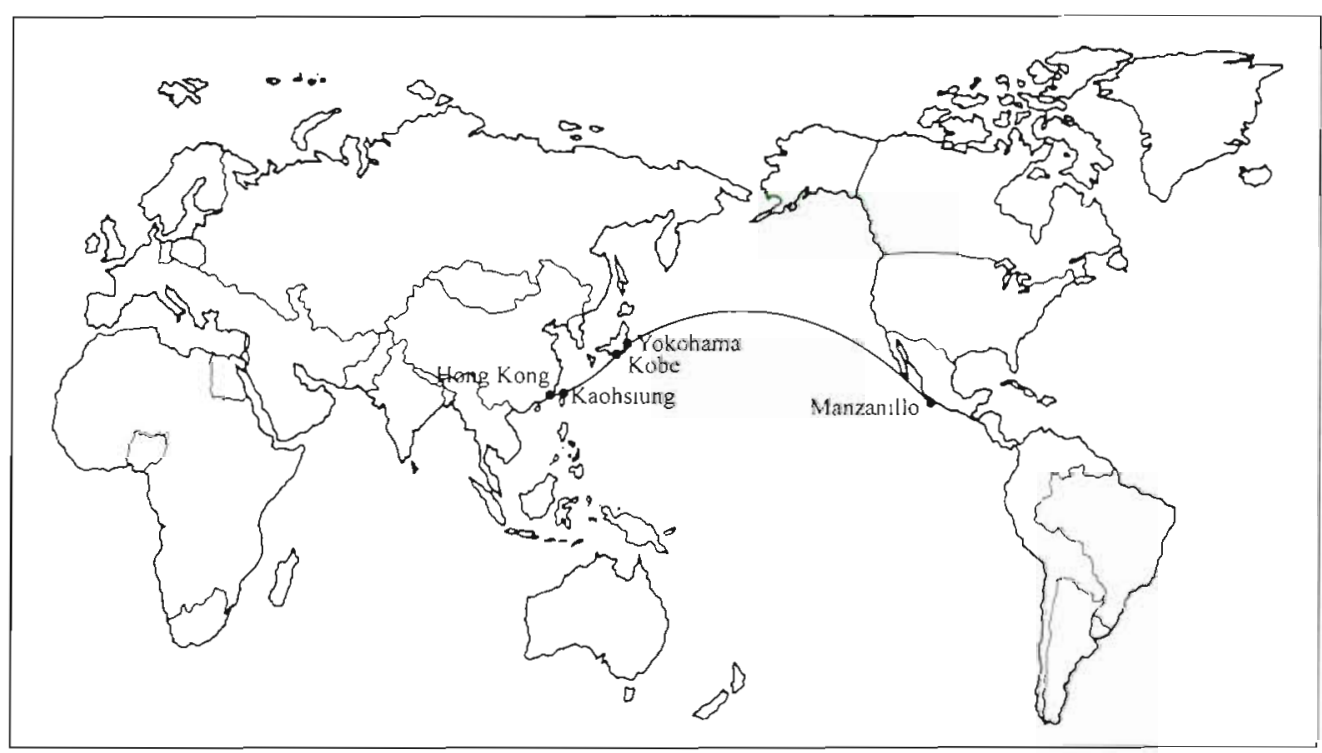

Fig. 1 Approximate route followed by the container ships en route to Hong Kong, China, from Manzanillo Harbour, Mexico, passing through Yokohama and Kobe, Japan, and Kaohsiung, Taiwan Harbour 
Kong, China. Of the 34 ships, 14 exchanged ballast water (reballasting) in the open ocean (>2000 $\mathrm{m}$ depth) en route to Hong Kong. We concluded from the Oakland study that mid-ocean exchange of ballast water reduced the total abundance of harmful diatoms and dinoflagellates by about $87 \%$ (and $83 \%$ for total abundance of diatoms and dinoflagellates). In the present study, the container ships were much older and the passage to Hong Kong during the study period was made only 9 times. The residual ballast water in these older ships appeared to contain more sediment and more encysted species. This greatly reduced the effectiveness of their mid-ocean exchange.

\section{METHODS}

Sample collection. For the sake of consistency with earlier studies, only the forward (bow) ballast water tank (tank no. 1) was sampled. The number of diatom and dinoflagellate species in the open ocean reballasted water were compared with those transported to Hong Kong from Manzanillo with and without reballasting. The 3 ships that we studied were built in the mid 1980s, some 15 yr ago, and were characterized as being 'older ships' in terms of their ballast water discharge systems. Older ships retain a larger amount of ballast water as they were not designed with open ocean reballasting in mind. In rough seas the last $5 \%$ of the ballast water can momentarily shift away from the intake funnel, allowing air to pass up the intake into the pump and making further pumping useless (Captain Li Wai Man pers. comm.).

A small diameter copper line (ca $1.4 \mathrm{~cm}$ inner diameter) equipped with a standard flowmeter was connected to the discharge pipe of ballast tank no. 1 . Before any sampling took place, the ballast water was pumped from tank no. 1 for several minutes to insure that the water in the line was actually the ballast water from tank no. 1. A total of $100 \mathrm{l}$ of water was then passed through the copper line and a $10 \mu \mathrm{m}$ mesh plankton net. About $50 \mathrm{ml}$ of concentrate resulted and this was preserved in Lugol's iodine solution. The $50 \mathrm{ml}$ preserved sample was further concentrated by sedimentation. After $24 \mathrm{~h}$, the top $30 \mathrm{ml}$ of the sample was decanted, leaving $20 \mathrm{ml}$ of concentrate in the labeled vial. On 2 occasions in 1998, only $80 \mathrm{l}$ and 501 of ballast water was sampled because of low water pressure in the ballast tank.

The temperature and salinity of the ballast water were measured using a Horiba water quality checker (Model U-10). Between June 1996 and January 1998, 4 ballast water samples from Manzanillo Bay and 5 ballast water samples from the open ocean were evaluated.

Cell counts. The concentrated sample $\left(20 \mathrm{ml} \mathrm{vial}^{-1}\right)$ was shaken (not swirled) to make it homogenous, and a total of $0.025 \mathrm{ml}$ was removed using a Gilson Pipetman and placed on a clean glass slide. This $0.025 \mathrm{ml}$ sample was examined using an Olympus research microscope. Only diatoms and dinoflagellates were recorded as these were always the most abundant phyla. Species from these 2 phyla were identified using the following references: Yamaji (1984), Jin et al. (1985, 1992), Larsen \& Moestrup (1989), Fukuyo et al. (1990), Hallegraeff (1991), Villac et al. (1993), Hasle \& Fryxell (1995), Taylor et al. (1995), Cheng et al. (1996) and Tomas (1996). Phytoplankton in 3 replicate counts of $0.025 \mathrm{ml}$ was examined. A minimum of 500 individuals were counted for each $0.025 \mathrm{ml}$ sample. The density of each algal species was calculated as number of organisms per litre.

Samples were also analysed using an SEM in order to determine the presence of harmful species of diatoms (e.g. Pseudonitzschia species) and dinoflagellates which could not be identified to species under the light microscope.

\section{RESULTS}

\section{Ballast water characteristics}

The dates and locations of ballast water exchanges are provided in Table 1. The characteristics of open ocean and Manzanillo Harbour ballast water are described in Tables 2 \& 3 respectively. The temperature of ballast water from the open ocean reballasting

Table 2. $\mathrm{pH}$, conductivity, turbidity, temperature and salinity of the ballast water from the open ocean upon delivery to Hong Kong

\begin{tabular}{|c|c|c|c|c|c|c|c|c|}
\hline Sample date & $\begin{array}{c}\text { Water } \\
\text { volume (1) }\end{array}$ & $\begin{array}{c}\text { Concentrated water } \\
\text { volume }(\mathrm{ml})\end{array}$ & $\begin{array}{l}\text { Net size } \\
(\mu \mathrm{m})\end{array}$ & $\mathrm{pH}$ & $\begin{array}{l}\text { Conductivity } \\
\left(\mathrm{mS} \mathrm{cm}^{-1}\right)\end{array}$ & $\begin{array}{l}\text { Turbidity } \\
\text { (NTU) }\end{array}$ & $\begin{array}{l}\text { Temperature } \\
\left({ }^{\circ} \mathrm{C}\right)\end{array}$ & $\begin{array}{l}\text { Salinity } \\
(\%)\end{array}$ \\
\hline 24 Nov 1996 & 100 & 20 & 10 & 8.25 & 53.8 & 2 & 24.5 & 35.6 \\
\hline 16 Feb 1997 & 100 & 20 & 10 & 8.27 & 54.3 & 2 & 24.6 & 35.8 \\
\hline 30 Mar 1997 & 100 & 20 & 10 & 8.05 & 51.9 & 0 & 20.5 & 34.2 \\
\hline $12 \operatorname{Jan} 1998$ & 80 & 16 & 10 & & & & & \\
\hline $19 \operatorname{Jan} 1998$ & 50 & 10 & 10 & 8.18 & 52.0 & 2 & 18 & 34.4 \\
\hline
\end{tabular}


Table 3. $\mathrm{pH}$, conductivity, turbidity, temperature and salinity of the ballast water from Manzanillo Harbour upon delivery to Hong Kong

\begin{tabular}{|ccccccccc|}
\hline Sample date & $\begin{array}{c}\text { Water } \\
\text { volume (1) }\end{array}$ & $\begin{array}{c}\text { Concentrated water } \\
\text { volume (ml) }\end{array}$ & $\begin{array}{c}\text { Net size } \\
(\mu \mathrm{m})\end{array}$ & $\mathrm{pH}$ & $\begin{array}{c}\text { Conductivity } \\
\left(\mathrm{mS} \mathrm{cm}^{-1}\right)\end{array}$ & $\begin{array}{c}\text { Turbidity } \\
(\mathrm{NTU})\end{array}$ & $\begin{array}{c}\text { Temperature } \\
\left({ }^{\circ} \mathrm{C}\right)\end{array}$ & $\begin{array}{c}\text { Salinity } \\
(\%)\end{array}$ \\
\hline 9 Jun 1996 & 100 & 20 & 10 & 7.93 & 53.8 & 3.5 & 27.5 & 35.6 \\
23 Jun 1996 & 100 & 20 & 10 & 8.03 & 52.2 & 2 & 29 & 34.3 \\
4 Aug 1996 & 100 & 20 & 10 & 8.02 & 51.2 & 0 & 32 & 32.7 \\
15 Apr 1997 & 100 & 20 & 10 & 7.44 & 52.9 & 0 & 25.5 & 35.1 \\
\hline
\end{tabular}

areas near Manzanillo Harbour ranged from 18 (19 January 1998 ) to $24.6^{\circ} \mathrm{C}$ (16 February 1997) (Table 2$)$. The temperature of ballast water from Manzanillo Harbour ranged from 25.5 (15 April 1997) to $32^{\circ} \mathrm{C}$ (4 August 1996) (Table 3). The salinity of the ballast water from the open ocean reballasting areas (locations from Table 1) varied from 34.2 to 35.8 (Table 2), while the salinity of ballast water from Manzanillo Harbour ranged from 32.7 to 35.6 (Table 3 ). Thus the water from Manzanillo Bay was significantly warmer and less saline than the water from the open ocean.

\section{Phytoplankton species composition}

A total of 30 diatom species and 4 dinoflagellate species were observed in the ballast water from the 4 voyages in which ships did not reballast with open ocean water during their voyage to Hong Kong. A total of 47 diatom species and 6 dinoflagellate species were observed in the ballast water from the 5 voyages in which ships did reballast in the open ocean. Lists of the diatoms and dinoflagellates found in the open ocean ballast water (53) and the Manzanillo Harbour ballast water (34) (Tables 4 \& 5) can be compared, but statistical analysis is only possible if the mean number of diatoms and dinoflagellates is analyzed. This analysis indicated that there was a significantly higher number of species from the open ocean $(\mathrm{p}<0.05$, mean $=25$ ) than from Manzanillo Harbour (mean = 14, Fig. 2).

All 4 of the common diatom species in Manzanillo Harbour ballast water (Bacteriastrum varians, Chaetoceros denticulatum, Pseudonitzschia pungens, and Skeletonema costatatum) were marine planktonic species which are widely distributed (Tomas 1996). None were new to Hong Kong.

\section{Phytoplankton abundance}

Phytoplankton abundance in the opean ocean was significantly lower $(\mathrm{p}<0.05)$ than that in Manzanillo Harbour ballast water $\left(436\right.$ cells $1^{-1}$ in the open ocean reballasted water versus 838 cells $I^{-1}$ in the ballast water from Manzanillo Harbour, Fig. 3). Only 5 species (Chaetoceros lorenzianum, Eucampia zoodiacus, Pseudonitzschia spp., Stephanopyxis palmeriana and Skeletonema costatum, Table 4) reached densities of more than 50 cells $1^{-1}$ from the open ocean samples versus 8 species from Manzanillo Bay (Chaetoceros affine, C. lorenzianum, Ditylum brightwellii, E. zoodiacus, Rhizosolenia delicatula, S. palmeriana, Pseudonitzschia diatoms and $S$. costatum, Table 5). The total number of harmful individuals in the 5 replicated samples from reballasted ships was $129,54,195,173$ and 397 (mean $=190$ ). The total number of harmful individuals in the 4 samples from Manzanillo Bay was $480,463,488$ and 497 (mean $=482$ ).

\section{DISCUSSION}

Most container ship ballast water is stored in dedicated ballast tanks and is used to trim and stabilise the vessel and to improve its manoeuverability when cargo is absent (Hutchings, 1992). Upon arrival at a destination, ships discharge their ballast water as cargo is loaded. Discharged ballast water mixes with the receiving waters and, if the environmental conditions are appropriate, some of the discharged individuals in the ballast water may reproduce and colonise the receiving waters (Carlton 1985).

Pseudonitzschia spp. were difficult to identify to species using only the light microscope. $P$. pungens had a characteristic shape and this fact plus its large cell to cell overlap (>20\% overlap) permitted its separation from the other common Pseudonitzschia species. $P$. multiseries (Zhang \& Dickman 1998) was positively identified from Manzanillo Harbour ballast water from SEM photomicrographs. P. multiseries can be a source of amnesic shellfish poisoning (ASP) (Garrison et al. 1992, Villac et al. 1993). This toxic species has been reported for the Atlantic waters of North America, Europe and South America and in the Pacific waters of North America and Northeast Asia (Garrison et al. 1992, Villac et al. 1993). Another potentially toxic species, $P$. pseudodelicatissima, was observed in the Manzanillo Harbour ballast water but was absent in the open ocean ballast water. $P$. pseudodelicatissima 
Table 4. Mean and total abundance (cells $1^{-1}$ ) of diatoms and dinoflagellates in the open ocean ballast water delivered to Hong Kong

\begin{tabular}{|c|c|c|c|c|c|c|c|}
\hline Species & 4 Nov 1996 & 16 Feb 1997 & 30 Mar 1997 & 12 Jan 1998 & $19 \operatorname{Jan} 1998$ & Total & Mean \\
\hline \multicolumn{8}{|l|}{ Diatoms } \\
\hline Actinoptychus pericavatus & 3 & 7 & & & & 10 & 2 \\
\hline Achnanthes delicatula & 4 & 5 & & & & 9 & 2 \\
\hline Asterionellopsis glacialis & & & 3 & 8 & 24 & 35 & 7 \\
\hline Bacteriastrum varians & 5 & & & 8 & & 13 & 3 \\
\hline Biddulphia mobliensis & 3 & & & & & 3 & 1 \\
\hline Chaetoceros affine & & & 4 & 5 & 8 & 17 & 3 \\
\hline Chaetoceros curvisetum & & & 15 & & & 15 & 3 \\
\hline Chaetoceros denticulatum & & 23 & & & & 23 & 5 \\
\hline Chaetoceros lorenzianum & 87 & 5 & 24 & 80 & 68 & 264 & 53 \\
\hline Chaetoceros messanense & 16 & & 8 & & & 24 & 5 \\
\hline Corethron pelagicum & & 8 & 5 & 10 & 8 & 31 & 6 \\
\hline Coscinodiscus asteromphalus & & 1 & & 3 & & 4 & 1 \\
\hline Coscinodiscus lineatus & & 4 & & & 5 & 9 & 2 \\
\hline Coscinodiscus marqinato-lineatus & 5 & 5 & 12 & & & 22 & 4 \\
\hline Coscinodiscus radiatus & & 7 & 3 & 5 & 24 & 39 & 8 \\
\hline Cyclindrotheca clasterium & & & 7 & 8 & & 15 & 3 \\
\hline Cyclotella striata & 7 & 9 & 4 & 8 & 4 & 32 & 6 \\
\hline Diploneis bombus & 3 & 3 & & & & 6 & 1 \\
\hline Ditylum brightwellii & 3 & 1 & & & 8 & 12 & 2 \\
\hline Eucampia zoodiacus & 3 & 41 & & 32 & 72 & 148 & 30 \\
\hline Guinardia flaccida & 17 & 4 & & & & 21 & 4 \\
\hline Hemiaulaus hackii & 4 & & 1 & & & 5 & 1 \\
\hline Lauderia borealss & 1 & & & & & 1 & 0 \\
\hline Leptocylindrus danicus & 5 & & & & & 5 & 1 \\
\hline Melosira nummuloides & 7 & & & & & 7 & 1 \\
\hline Melosira sulcata & & 5 & 6 & 40 & & 51 & 10 \\
\hline Navicula cancellate & & 3 & 3 & 5 & 5 & 16 & 3 \\
\hline Navicula distans & 3 & & & & & 3 & 1 \\
\hline Nitzschia longissima & 12 & & & 5 & & 17 & 3 \\
\hline Pinnularia viridis & & & 4 & & & 4 & 1 \\
\hline Pseudonitzschia spp. & 52 & 8 & & 36 & 24 & 120 & 24 \\
\hline Pleurosigma normanui & & 4 & 3 & 8 & & 15 & 3 \\
\hline Rhaphoneis amphiceros & & & & & 8 & 8 & 2 \\
\hline Rhizosolenia alata & 1 & & 3 & 3 & & 7 & 1 \\
\hline Rhizosolenia calcat & & & 5 & & & 5 & 1 \\
\hline Rhizosolenia delicatula & 5 & 5 & & & & 10 & 2 \\
\hline Rhizosolenia hebetata forma. semispina & 1 & 3 & & 8 & 8 & 20 & 4 \\
\hline Rhizosolenia setigera & 20 & & & & & 20 & 4 \\
\hline Rhizosolenia stolterforthii & 16 & & 3 & & 5 & 24 & 5 \\
\hline Rhizosolenia styliformis & 8 & 13 & & & & 21 & 4 \\
\hline Rhaphoneis amphiceros & & & & & 12 & 12 & 2 \\
\hline Skeletonema costatum & 69 & 40 & 192 & 124 & 325 & 750 & 150 \\
\hline Stephanopyxis palmeriana & & 80 & & 96 & & 176 & 35 \\
\hline Streptotheca thamensis & 3 & & & & & 3 & 1 \\
\hline Thalassiosira eccentrica & & & 5 & & 5 & 10 & 2 \\
\hline Thalassiosira pacifica & & 8 & 3 & & & 11 & 2 \\
\hline Thalassiothrix frauenfeldii & 3 & & 1 & 35 & & 39 & 8 \\
\hline \multicolumn{8}{|l|}{ Dinoflagellates } \\
\hline Ceratium fusus & 8 & & & 5 & 24 & 37 & 7 \\
\hline Ceratium tripos & & 3 & & & & 3 & 1 \\
\hline Gonyaulax spinifera & 3 & 2 & 2 & 5 & 5 & 17 & 3 \\
\hline Peridinium perardiforme & & & 7 & & & 7 & 1 \\
\hline Prorocentrum balticum & & 2 & & & & 2 & 0 \\
\hline Prorocentrum micans & & 4 & & & & 4 & 1 \\
\hline Total abundance of phytoplankton & 377 & 303 & 323 & 537 & 642 & 2182 & 436 \\
\hline SD & 47 & 108 & 88 & 76 & 132 & 451 & 90 \\
\hline Total number of species & 30 & 28 & 24 & 22 & 19 & 123 & 25 \\
\hline $\mathrm{SD}$ & 2 & 3 & 2 & 2 & 1 & 10 & 2 \\
\hline Total abundance of harmful species & 129 & 54 & 195 & 173 & 397 & 948 & 190 \\
\hline $\mathrm{SD}$ & 23 & 42 & 64 & 34 & 69 & 232 & 46 \\
\hline Number of harmful species & 3 & 4 & 3 & 4 & 4 & 18 & 4 \\
\hline $\mathrm{SD}$ & 0 & 1 & 1 & 0 & 1 & 3 & 1 \\
\hline
\end{tabular}


Table 5. Mean and total abundance (cells ${ }^{-1}$ ) of diatoms and dinoflagellates in the Manzanillo Harbour ballast water delivered to Hong Kong

\begin{tabular}{|c|c|c|c|c|c|c|}
\hline Species & 9 Jun 1996 & 23 Jun 1996 & 4 Aug 1996 & 15 Apr 1997 & Total & Mean \\
\hline \multicolumn{7}{|l|}{ Diatoms } \\
\hline Bacteriastrum varians & 39 & & & 8 & 47 & 12 \\
\hline Chaetoceros affine & 100 & 20 & & & 120 & 30 \\
\hline Chaetoceros compressum & & 47 & 40 & & 87 & 22 \\
\hline Chaetoceros curvisetum & 40 & 40 & & 5 & 85 & 21 \\
\hline Chaetoceros denticulatum & & & 10 & & 1.0 & 3 \\
\hline Chaetoceros lorenzianum & 47 & 60 & 260 & 1.6 & 383 & 96 \\
\hline Coscinodiscus asteromphalus & & & & 5 & 5 & 1 \\
\hline Coscinodiscus radiatus & 30 & 10 & 17 & & 57 & 14 \\
\hline Coscinodiscus rothii & & & & 22 & 22 & 6 \\
\hline Diploneis bombus & & & 7 & & 7 & 2 \\
\hline Ditylum brightwellii & & 183 & 10 & & 193 & 48 \\
\hline Eucampia zoodiacus & & & 17 & 88 & 105 & 26 \\
\hline Hemiaulaus hackii & & & & 18 & 18 & 5 \\
\hline Lauderia borealis & & & & 40 & 40 & 10 \\
\hline Melosira nummuloides & 37 & & & & 37 & 9 \\
\hline Nitzschia delicatissima & 10 & & & & 10 & 3 \\
\hline Nitzschia longissima & & & 7 & & 7 & 2 \\
\hline Pseudonitzschia spp. & 220 & 423 & 47 & 68 & 758 & 190 \\
\hline Pleurosigma normanii & & & 10 & & 10 & 3 \\
\hline Rhizosolenia alata & 20 & & & & 20 & 5 \\
\hline Rhizosolenia calcar & 13 & & & & 13 & 3 \\
\hline Rhizosolenia delicatula & & & 57 & & 57 & 14 \\
\hline Rhizosolenia hebetata forma semispina & & & 7 & 12 & 19 & 5 \\
\hline Rhizosolenia stolterforthii & & & & 20 & 20 & 5 \\
\hline Rhaphoneis amphiceros & 17 & & & & 17 & 4 \\
\hline Skeletonema costatum & 220 & 33 & 433 & 424 & 1110 & 278 \\
\hline Stephanopyxis palmeriana & & & & 160 & 160 & 40 \\
\hline Streptotheca thamensis & & & 37 & & 37 & 9 \\
\hline Thalassiosira condensata & & & 33 & & 33 & 8 \\
\hline Thalassiosira pacifica & & & 17 & & 17 & 4 \\
\hline \multicolumn{7}{|l|}{ Dinoflagellates } \\
\hline Ceratium furca & & 10 & 12 & & 22 & 6 \\
\hline Dinophysis forthii & & 7 & 8 & & 15 & 4 \\
\hline Gonyaulax spinifera & & 10 & & 8 & 18 & 5 \\
\hline Prorocentrum micans & 40 & & & 5 & 45 & 11 \\
\hline Total abundance of phytoplankton & 813 & 753 & 887 & 899 & 3352 & 838 \\
\hline $\mathrm{SD}$ & 140 & 55 & 106 & 132 & 433 & 108 \\
\hline Total number of species & 13 & 11 & 18 & 15 & 57 & 14 \\
\hline $\mathrm{SD}$ & 1 & 2 & 1 & 1 & 5 & 1 \\
\hline Total abundance of harmful species & 480 & 463 & 488 & 497 & 1928 & 482 \\
\hline $\mathrm{SD}$ & 92 & 161 & 60 & 123 & 436 & 109 \\
\hline Number of harmful species & 3 & 3 & 3 & 3 & 12 & 3 \\
\hline SD & 1 & 0 & 1 & 0 & 2 & 1 \\
\hline
\end{tabular}

(Zhang \& Dickman 1998) was first identified in Hong Kong waters in 1996 by Dickman (1996) and Dickman et al. (1997).

In addition to the toxic diatoms, there were a number of species of the diatom genus Chaetoceros, with long needle-like spines which can cause mechanical damage to fish and invertebrate gills (Bell 1961). Blooms of these species pose an economic threat to finfish and shellfish fisheries (Shumway 1992). The gills of Atlantic salmon in Puget Sound, Washington, became clogged with mucus following a bloom of $C$. concavi- cornis. The mechanical damage to the gills resulted in excessive amounts of mucus being secreted. The mucus-clogged gills resulted in a deficiency of oxygen in the gill tissues and an excessive amount of carbon dioxide in the blood (Rensel 1993). High mortality in this commercially valuable Atlantic salmon species was associated with the $C$. concavicornis bloom (Rensel 1993).

A third group of harmful algae have neither toxins nor needle-like spines; however, they form dense blooms which rapidly decay, lowering the dissolved 


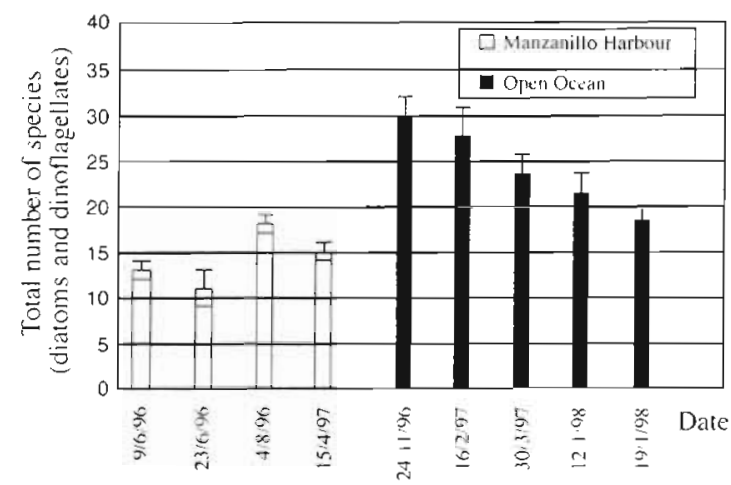

Fig. 2. Total number of diatom and dinoflagellate species in the open ocean reballasted water and in the Manzanillo ballast water delivered to Hong Kong. Dates given as d/mo/yr

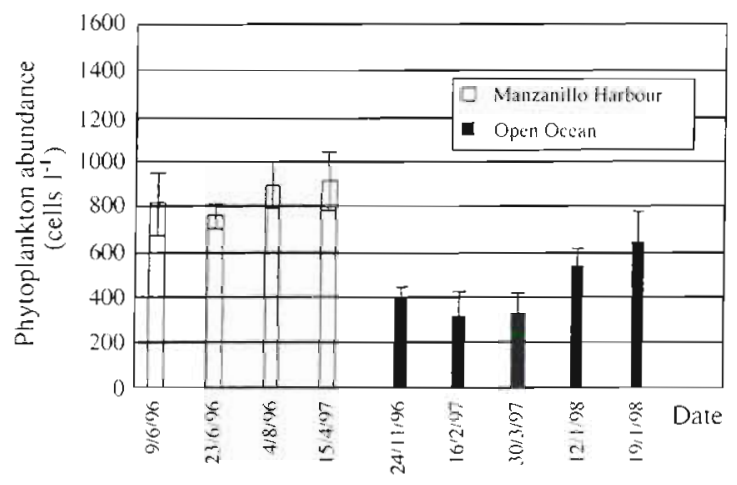

Fig. 3. Total diatom and dinoflagellate abundance (cells $\mathrm{l}^{-1}$ ) in the open ocean ballast water and in the Manzanillo ballast water delivered to Hong Kong. Dates given as d/mo/yr

oxygen concentrations in the water to the point that the resulting hypoxia leads to mass mortality of fish and invertebrates (Richardson 1997). Skeletonema costatum has been reported to produce hypoxic conditions in the nutrient enriched coastal waters of many parts of the globe (ICES 1992) and to cause gill lesions and mortality in seawater-pen-reared Atlantic salmon (Kent et al. 1995). S. costatum was the most common diatom from both our open ocean and Manzanillo Harbour ballast water samples. Its presence in the open ocean samples was puzzling as this is a coastal species which does not usually become abundant in the open ocean waters (Tomas 1996). It is suggested that its presence indicates that substantial amounts of Manzanillo Bay water was retained in ballast tank no. 1 following open ocean reballasting. Ballast water 'topping up' in Japan and/or Taiwan did not occur according to the log book entries which we were shown for each of the cruises. During open ocean exchange (reballasting), approximately 1 to $5 \%$ of the Manzanillo ballast water was retained in ballast tank no. 1 due to the incomplete emptying of the ballast tank (Captain Li Wai Man pers. comm.). This retention of some of the original ballast water in the ballast tank is common to all container ships but the proportion of sediment at the bottom of the ballast tank is greater in older ships (Captain Li Wai Man pers comm.).

\section{Red tide species from Mexico}

Red tides in Mexico have become much more common in the last decade and are more common in the Gulf of California than in any other part of the country (Paez-Osuna et al. 1998). The southern end of the Gulf of California is located about $800 \mathrm{~km}$ to the northwest of Manzanillo (Fig. 1). The main toxic species described for 94 blooms from Mexican coastal waters were Gymnodinium catenatum (a common species in the ballast water delivered to Hong Kong) and Gonyaulax polyedra (Cortes-Altmirano et al. 1996). Although we did not report $G$. polyedra in the ballast water from Manzanillo, this may be because of our difficulties with its taxonomy. Dodge (1989) placed $G$. polyedra in the genus Lingulodinium.

Urban wastewater discharges have been correlated with blooms of Prorocentrum dentatum and P. minimum (Cortes-Altamirano \& Agraz-Hernandez 1994). The major sources of coastal nutrients in Mexico are associated with agricultural discharges (141232 t nitrogen $\mathrm{yr}^{-1}$ and $35272 \mathrm{t}$ phosphorus $\mathrm{yr}^{-1}$ ) (PaezOsuna et al. 1998).

The estuarine dinoflagellate Protoperidinium pentagonum (Gran) Balech (Tomas 1996) was found in Manzanillo Bay ballast water. There are numerous accounts of this species forming dense blooms and red tides which can, in time, produce hypoxia, as noted above for Skeletonema costatum. There were no accounts of $P$. pentagonum producing a toxin (Smayda \& Shimizu 1993).

The abundance of harmful species in the open ocean ballast water was generally much lower than in the ballast water from Manzanillo Harbour. However, after $21 \mathrm{~d}$ at sea in the complete absence of light, few phototrophic cells survived. Similar observations were made by Yoshida et al. (1996).

\section{Impacts of voyage length on species survival}

Data from Williams et al. (1988), Hallegraeff \& Bolch (1992), Hutchings (1992), Carlton \& Geller (1993). Locke et al. (1993), Rigby et al. (1993), Yoshida et al. (1996), Chu et al. (1997) and Ruiz et al. (1997) support the hypothesis that the longer the sea voyage (days) 
the fewer the number of phototrophic species observed at the end of the voyage. The lack of light in ballast tanks may be the major reason for the poor survival of autotrophic species (Yoshida et al. 1996). According to Hallegraeff \& Bolch (1992), dinoflagellate physiology permits them to survive for only 2 to $4 \mathrm{~d}$ in the dark. Thereafter they either switch to chemotrophy, die or encyst. According to Provasoli \& McLachlan (1963), most pelagic diatoms and photosynthetic dinoflagellates failed to exhibit chemotrophic adaptations.

\section{Temperature and salinity}

It is argued that temperature has a strong influence on marine invasions of exotics (Schneider 1993) because it prevents some exotics from establishing at release sites where water temperatures are cold relative to those assoclated with the invading species. Evidence for this comes from the study of thermal plume species near power plants where species include exotics not found in local waters (Paine 1993). We have observed that dinoflagellates adapted to the 15 to $20^{\circ} \mathrm{C}$ water temperatures in Oakland Harbour in summer only became abundant in Hong Kong waters during winter when temperatures were comparable (Zhang \& Dickman 1.998)

In addition, ships sailing from Manzanillo arch northward (Fig. 1), passing through cold temperate waters, and in less than $12 \mathrm{~h}$ the temperature of the sea and that of the ballast water reach equilibrium (Captain Li Wai Man pers. comm.). Some tropical species may be unable to survive exposure to these low temperatures. This fact, plus the longer voyage time (21 vs 16 d) may explain why diatom and dinoflagellate abundance in ballast water from Manzanillo Bay

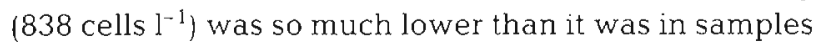
from Oakland Harbour $\left(6600\right.$ cells $\left.1^{-1}\right)$, where the species were likely to be more tolerant of low temperature.

\section{Effectiveness of mid-ocean exchange (reballasting)}

Williams et al. (1988) suggested that open ocean exchange was an effective way to reduce the number of harmful species in ballast water. The effectiveness of open ocean exchange varies with different hydrologic conditions, different ship designs and different marine locations for reballasting. In addition, tropical species that are not adapted to low temperature may succumb during long voyages which encounter northern waters at low temperatures during the northern arch of the voyage as described in the present study.
Locke et al. (1993) reported that the effectiveness of mid-ocean exchange was in the range of 67 to $86 \%$ in eliminating harmful non-indigenous spices (i.e. those brackish-water-tolerant organisms common to coastal areas). In our initial study of ships from Oakland, open ocean exchange was $83 \%$ effective while, in the present study of ships from Mexico, the effectiveness of open ocean exchange fell to $48 \%$ (open ocean exchange of Manzanillo Harbour ballast water reduced diatom and dinoflagellate abundance in the ballast

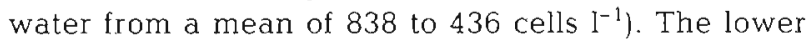
number of individuals in the Manzanillo study was ascribed to the longer period of light-free isolation (21 d) and to the fact that Manzanillo Bay species were adapted to much higher temperatures than the Oakland Harbour species and, as a result, they were more susceptible to cold shock as the ships entered the northernmost portion of their arch (Fig. 1). When the container ship arched northward and temperatures of the sea dropped to $15^{\circ} \mathrm{C}$, many tropical species may have succumbed

Reballasting involves the emptying and then refilling of ballast tanks in the open ocean. It is estimated from the ballast tank volume gauges that about 95 to $99 \%$ of the original ballast water from the ballast tanks of newer OOCL ships was removed during mid-ocean reballasting (Captain Li Wai Man pers, comm.). For a ballast tank in which all organisms are homogenously distributed throughout the water column, this method would be close to $95-99 \%$ effective. However, the residual ballast water (i.e. the water remaining at the bottom of the ballast tank after the tank has been pumped) is likely to contain organisms at densities higher than those observed in the plankton samples which we took from ships sailing directly from Manzanillo without reballasting in the open ocean. In the view of Rigby \& Hallegraeff (1993), residual water often contains many more planktonic organisms than the water from the surface of the ballast tank. In older container ships, sediment is accumulated in the bottom of the ballast tank. As a result, the last 1 to $5 \%$ of the ballast water is likely to contain far more species because of these sediments (Rigby \& Hallegraeff 1993). Hallegraeff \& Bolch (1992) studied ballast water exchange in older ships and concluded that 14 of 32 vessels that they studied still contained significant numbers of dinoflagellate cysts even after mid-ocean exchange.

The OOCL ships involved in the Oakland to Hong Kong study were new container ships with modern ballast water exchange designs. The new OOCL ships were designed with an inverted funnel positioned within a decimetre of the bottom of the ballast tank, making sediment removal highly efficient during ballast exchange. This has resulted in ballast tanks that 
are virtually sediment-free. The Manzanillo ships, by contrast, were about 15 yr old and did not possess modern ballast water exchange systems.

Most of the studies on mid-ocean exchange tested its effectiveness by comparing the number of species taken on as ballast water with the number delivered when the ballast water was discharged. This study and the Oakland study were unique because they compared the number and abundance of species in the ballast water arriving in Hong Kong from ships coming directly from Manzanillo with those from ships coming from Manzanillo that had reballasted in the open ocean.

If sediments near the bottom of the ballast tanks contain cysts of diatoms and dinoflagellates and if the water just above these sediments contains an over-representation of cells of these phyla, then removing all but the bottom $5 \%$ of the ballast water during reballasting with open ocean water may not provide as effective a means of getting rid of harmful species as originally anticipated. Modern container ships in which little or no sediment remains in the bottom of the ballast tanks have paved the way for effective open ocean exchange.

Compared with various treatment techniques, midocean exchange of ballast water is relatively inexpensive and environmentally friendly (Rigby \& Hallegraeff, 1996). Unlike coastal and estuarine waters that are rich in nutrients and planktonic life forms, open ocean waters contain relatively few organisms and low nutrient levels. Open ocean organisms are considered unlikely to adapt to coastal environments, and hence the probability of transferring unwanted organisms is greatly reduced (Williams et al. 1988). Initial thoughts were that mid-ocean exchange would prove to be an effective control measure. However, exchange of ballast water as a preventive strategy is not yet fully supported because it is rarely $100 \%$ effective in eliminating harmful species.

\section{Conclusion}

The efficacy of reballasting with open ocean water was far higher for new ships $(83 \%$; Zhang \& Dickman 1.998) than for older ships ( $48 \%$ effective). This is probably because the reballasting design of the older ships is not as efficient in removing the water near the bottom of the ballast tanks. This water of ten has unusually high densities of resting cells and cysts (Carlton 1985).

Acknowledgements. We are grateful to the Orient Overseas Container Lines Ltd. (OOCL) Hong Kong for their co-operation and assistance during this study and to Mr Lambros Bakountouzis for unstalling the flowmeter and making the initial contact with container ship company personnel to permit our sampling of the ballast water. The Electron Microscope Unit of the University of Hong Kong made its SEM available to us so we could better identify some of our species. We are also grates!l to The University of Hong Kong for the studentship support of the second author.

\section{LITERATURE CITED}

Bell GR (1961) Penetration of spines from a marine diatom into the gill tissue of lingcod (Ophidon elongatum). Nature $192: 279-280$

Carlton JT (1985) Transoceanic and interoceanic dispersal of coastal marine organism: the biology of ballast water. Oceanogr Mar Biol Annu Rev 23:313-371

Carlton JT (1996) Pattern, process and prediction in marine invasion ecology. Biol Conserv 78:97-106

Carlton JT, Geller B (1993) Ecological roulette: the global transport of non-indigenous marine organisms. Science 261:78-82

Cheng Z, Gao Y, Dickman MD (1996) Colour plates of the diatoms. China Ocean Press, Beijing

Chu KH, Tam PF, Fung CH, Chen QC (1997) A biological survey of ballast water in container ships entering Hong Kong. Hydrobiologia 352:201-206

Cohen AN, Carlton JT (1996) Nonindigenous species in a United States estuary: a case history of the economic and ecological effects of biological invasions in the San Francisco and Delta region. Report to the U.S. Fish \& Wildlife Service

Cortes-Altamirano R, Agraz-Hernandez C (1994) Presencia de Prorocentrum minimum (Pav.) Schiller estanques para cultivo de camaron. Cienc Mar UAS 13:11-16

Cortes-Altmirano R, Hernendez-Becril DU, Luna-Soria R (1996) Red tides in Mexico: a review. In: Yasumoto T, Oshima Y, Fukuyo Y (eds) Harmful and toxic algal blooms. Intergovernmental Oceanographic Commission of UNESCO, 1996. UNESCO, Paris, p 101-104

Dickman MD (1996) A search for domoic acid producing diatoms in Hong Kong waters. In: Yasumoto T, Oshima $Y$, Fukuyo $Y$ (eds) Harmful and toxic algal blooms. Intergovermmental Oceanographic Commission of UNESCO, 1996. UNESCO, Paris, p 59-62

Dickman MD, Qi Y, Zheng L (1997) Toxic diatoms belonging to the genus Pseudonitzschia from the coast of Southern China. In: Saxena NK (ed) Proc Pac Congr Mar Sci Technol. PACON International, Honolulu, p 434

Dodge JD (1989) Some revisions of the family Gonyaulacaceae (Dinophyceae) based on a scanning electron microscope study. Bot Mar 32:275-289

Fukuyo Y, Takano H, Chihara M, Matsuoka K (1990) Red tide organisms in Japan-an illustrated taxonomic guide. Uchida Rokakuho, Tokyo

Garrison DL, Conrad SM, Ellers PP, Waldron M (1992) Confir-

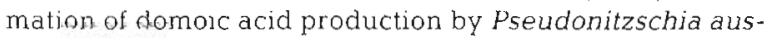
tralis (Bacillariophyceae) cultures. J Phycol 28:604-607

Hallegraeff GM (1991) Aquaculturists' guide to harmful australian microalgae. CSIRO Division of Fisheries, Hobart

Hallegraeff GM (1993) A review of harmful algal blooms and their apparent increase. Phycologia 32:79-99

Hallegraeff GM, Bolch CJ (1992) Transport of diatom and dinoflagellate resting spores in ships' ballast water: implications for plankton biography and aquaculture. J Plankton Res 14:1067-1084

Hasle GR, Fryxell GA (1995) Taxonomy of diatoms. In: Hallegraeff GM, Anderson DM Cembella AD (eds) Manual on 
harmful marine microalgae. UNESCO, IOC Manual and Guides 33:339-364

Hutchings P (1992) Ballast water introductions of exotic marine organisms into Australia: current status and management options. Mar Pollut Bull 25:196-199

ICES (1992) Report of the working group on the effects of harmful algal blooms on mariculture and marine fisheries. Int Coun Meet Paper 1992/No. 181

Jin DX, Cheng ZD, Lin JM, Liu SC (1985) Marine benthic diatoms in China (I). China Ocean Press, Beijing

Jin DX, Cheng ZD, Lin JM Liu SC (1992) Marine benthic diatoms in China (II) China Ocean Press, Beijing (in Chinese)

Jones MM (1991) Marine organisms transported in ballast water. A review of the Australian scientific position. Bureau of Rural Resources Bulletin, 11. Australian Government Printing Service, Canberra

Kent ML, Whyte JNC, La Trace C (1995) Gill lesions and mortality in seawater pen-reared Atlantic salmon Salmo salar associated with a dense bloom of Skeletonema costatum and Thalassiosira species. Dis Aquat Org 22:77-81

Larsen J, Moestrup $\varnothing$ (1989) Guide to toxic and potentially toxic marine algae. The Fish Inspection Service, Ministry of Fisheries, Copenhagen

Locke A, Reid DM, van Leeuwen HC, Sprules WG, Carlton JT (1993) Ballast water exchange as a means of controlling dispersal of freshwater organisms by ships. Can J Fish Aquat Sci 50:2086-2093

Paez-Osuna F, Guerrero-Galvan SR, Ruiz-Fernandez AC (1998) The environmental impact of shrimp aquaculture and the coastal pollution in Mexico. Mar Pollut Bull 36: $65-75$

Paine RT (1993) A salty and salutary perspective on global change. In: Kareiva PM, Kingsolver JG, Huey RB (eds) Biotic interactions and global change. Sinauer Associates Inc, Sunderland, p 347-355

Provasoli L, McLachlan JL (1963) Limited heterotrophy of some photosynthetic dinoflagellates. In: Oppenheimer $\mathrm{CH}$ (ed) Symp Mar Microb. Charles Thomas Publishers, Springfield, IL, p 105-113

Rensel JE (1993) Severe bloom hypoxia of Atlantic salmon (Salmo salar) exposed to the marine diatom Chaetoceros concavicornis. In: Smayda TJ, Shimizu Y (eds) Toxic phytoplankton blooms in the sea. Elsevier Science Publishing Co, Amsterdam, p 169-176

Richardson K (1997) Harmful or exceptional phytoplankton blooms in the marine ecosystem. Adv Mar Biol 31:302-385

Rigby GR, Hallegraeff GM (1993) Shipping ballast water trials on the bulk carrier M. V. Iron. Whyalla. AQIS Ballast Water Research Series, Report No. 2, Australian Government Publishing Service, Canberra

Rigby GR, Hallegraeff GM (1996) Ballast water controls to minimize the translation and establishment of toxic marine phytoplankton - what progress have we made

Editorial responsibility: Otto Kinne (Editor), Oldendorf/Luhe, Germany and where are we going? In: Yasumoto $T$, Oshima $Y$, Fukuyo Y (eds) Harmful and toxic algal blooms. Intergovernmental Oceanographic Commission of UNESCO, 1996. UNESCO, Paris, p 201-204

Rigby GR, Stevenson IG, Bolch CJ, Hallegraeff GM (1993) The transfer and treatment of shipping ballast waters to reduce the dispersal of toxic marine dinoflagellates. In: Smayda TJ, Shimizu Y (eds) Toxic phytoplankton blooms in the sea. Elsevier Science Publishing Co, Amsterdam, p $169-176$

Rigby GR, Taylor AH, Hallegraeff GM, Mills P (1995) Progress in research and management of ships' ballast water to minimise the transfer of toxic dinoflagellates. In: Lassus P, Arzul G, Erard E, Gentien P, Marcaillou C (eds) Harmful marine algal blooms. Lavoisier/Intercept, Paris, p 821-824

Ruiz GM, Carlton JT, Grosholz ED, Hines AH (1997) Global invasions of marine and estuarine habitats by non-indigenous species: mechanisms, extent and consequences. Am Zool 37:621-632

Schneider SH (1993) Scenarios of global warming. In: Kareiva PM, Kingsolver JG, Huey RB (eds) Biotic interactions and global change. Sinauer Associates Inc, Sunderland, p $347-355$

Shumway SE (1992) A review of the effects of algal blooms on shellfish and aquaculture. J Shellfish Res 11:556

Smayda TJ, Shimizu Y (eds) (1993) Toxic phytoplankton blooms in the sea. Elsevier Science Publishing Co, Amsterdam

Taylor FJR, Fukuyo Y, Larsen J (1995) Taxonomy of harmful dinoflagellates. In: Hallegraeff GM, Anderson DM, Cembella $\mathrm{AD}$ (eds) Manual on harmful marine microalgae UNESCO, IOC Manual and Guides 33:283-316

Tomas CR (1996) Identifying marine diatoms and dinoflagellates. Academic Press, San Diego

Villac MC, Roelke DL, Villareal TA, Fryxell GA (1993) Comparison of two domoic acid-producing diatoms: a review. Hydrobiologia 269/270:213-224

Williams RJ, Griffiths FB, Van der Wal EJ, Kelly J (1988) Cargo vessel ballast water as a vector for the transport of non-indigenous marine species. Estuar Coast Shelf Sci 26: $409-420$

Yamaji I (1984) Illustrations of the marine plankton of Japan. Hoikusha, Osaka

Yoshida M. Fukuyo Y, Murase T, Ikegami T (1996) On-board observations of phytoplankton viability in ships' ballast water tanks under critical light and temperature conditions. In: Yasumoto T, Oshima Y, Fukuyo Y (eds) Harmful and toxic algal blooms. Intergovernmental Oceanographic Commission of UNESCO, 1996. UNESCO, Paris, p 205-208

Zhang F, Dickman M (1998) Mid-ocean exchange of container vessel ballast water. 1. Seasonal factors affecting the transport of harmful diatoms and dinoflagellates. Mar Ecol Prog Ser 1.76:243-251

Submitted: May 22, 1998; Accepted: July 31, 1998

Proofs received from author(s): October 28, 1998 